\title{
Cadavers in anatomy classes: opinions of the students of Bursa Uludağ University School of Medicine
}

\author{
Nilgün Tuncel Çini ${ }^{1}$ (D), Serdar Babacan ${ }^{1}$ (D), İlker Mustafa Kafa ${ }^{1}$ (D), Sezer Erer Kafa ${ }^{2}$ (D) \\ ${ }^{1}$ Department of Anatomy, School of Medicine, Bursa Uludă̆ University, Bursa, Turkey \\ ${ }^{2}$ Department of Medical Ethics and History of Medicine, School of Medicine, Bursa Uludağ University Bursa, Turkey
}

\begin{abstract}
Objectives: Informing the medical students about the ethical aspects related to human cadavers has been an important issue that should be taken into consideration by anatomists. The purpose of the study was to evaluate the opinions of the students of the School of Medicine of Bursa Uludağ University, Turkey on the cadavers, prior to the anatomy education, and to determine the changes in attitudes towards the dead human body after basic and compulsory anatomy courses.

Methods: The first-year class students of the School of Medicine of Bursa Uludağ University were included in the study. The questionnaire was applied before and after the education on cadavers in Topographic Anatomy Committee. The on-line survey form was created and the link address was shared with e-mail and social media. Statistical analyses of the obtained data were performed using the SPSS 22.0 program.

Results: The first questionnaire was answered by 297 students and the second questionnaire by 212 students. In the survey applied before the anatomy education in Topographic Anatomy Committee, the percentage of positive opinions (agree and strongly agree) on "Human is a valuable asset. For this reason, the human body must be valued and respected during life and after death" was found to be $83.8 \%$ and this percentage increased to $95.3 \%$ in the later survey.

Conclusion: Anatomy education can not be effective without cadavers. We believe that the current study will be useful for educators in order to contribute to the medical students' awareness of humanity and privacy.
\end{abstract}

Keywords: cadaver; ethics; medical students; survey

Anatomy 2019;13(1):49-55 @2019 Turkish Society of Anatomy and Clinical Anatomy (TSACA)

\section{Introduction}

The thought of life after death and immortality led to the idea of preserving the human body after death in some societies. In addition, it has been possible to see that many scientists in history have been working on human or animal bodies with the aim of recognizing the human body. ${ }^{[1-3]}$ Andreas Vesalius, one of the important names of anatomy, laid the foundations of medical education today with his cadaver dissections accompanied by his students in public theaters in Padua. The lesson on cadaver with an instructor has been a kind of continuation of modern anatomy education in our era. ${ }^{[4]}$

Because anatomy is a common language in medicine and clinical practices, anatomy education has been impor- tant for all health professionals, especially radiologists and surgeons. ${ }^{[5]}$ It has also been a science based on visually that sometimes requires spatial imagination. Because of its threee-dimensional structure, working with cadavers, especially with the presence of atlas and models, has increased the efficiency of practical courses of anatomy. ${ }^{[6]}$ In this way, it has been aimed to reinforce the theoretical education that has been learned with these training materials. ${ }^{[7,8]}$ The close sense of reality has made the cadaver a unique educational material for medical students. Despite its importance, it is difficult to supply cadavers for educational purposes. ${ }^{[3]}$

The aim of anatomy education with cadavers has not been only to get to know the human body, but also to show the students that human body is a respected entity 
within the frame of ethics. ${ }^{[9]}$ For these reasons, informing the students about ethical behaviors towards the cadaver has been a matter to be taken into consideration before the anatomy classes. Also, the initial contact with cadaver in the anatomy classes of the students can be important in the name of continuation of the medical education. ${ }^{[10]}$

Therefore, the aim of this study was to evaluate the students' opinions towards cadavers, used as educational material in the courses, prior to the anatomy education and to determine the changes in their attitudes after anatomy classes.

This study will enable educators to have ideas about increasing the effectiveness of anatomy classes with cadavers by taking student opinions prior to and after anatomy education.

\section{Materials and Methods}

The study was approved by the Uludağ University Ethics Committee (approval number 2017-13/93). Term I students who just started to Bursa Uludağ University School of Medicine were included in the study. The questionnaire was applied before (September 9th, 2017) and after (February 5th, 2017) the education on cadavers in the Topographic Anatomy Committee starting on January 2nd 2018. At the beginning of the Topographic Anatomy Committee, a panel presentation was made with the students on February 5th by anatomy and deontology professors. This panel was about the human cadavers, donations and the medical ethics. The on-line survey form was created and the link address "https://goo.gl/forms/ 8ySM8f9fQgDAeNng2" was shared with e-mails and social media. The first questionnaire was answered by

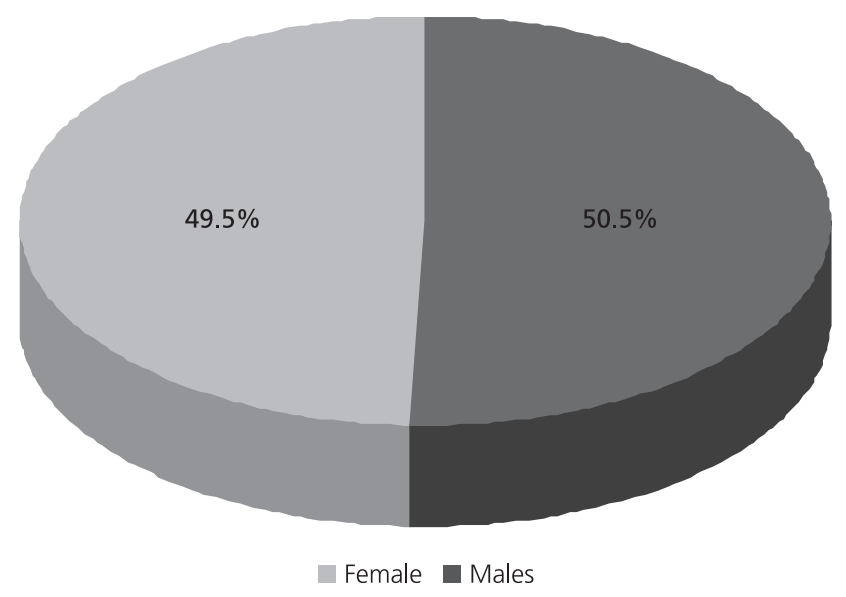

Figure 1. Age distribution of the participants of before the anatomy lessons.
297 students and the second one by 212 . Questionnaire consisted of 14 questions with 2 demographic information in Section A, four questions about "Cadaver and Ethics Education" in Section B, and "Opinions about Cadaver" in C Section using a 5-point Likert-type scale. In terms of the transparency of the answers to the questions, no data regarding the personal information of the volunteer was requested. The frequency distributions were analyzed using the Statistical Package for Social Sciences (SPSS for Windows, version 22.0, Chicago, IL, USA). and the answers given to the questionnaires' mean values were compared. In addition, Kruskal-Wallis and Mann Whitney-U analyses were used whether there were any differences before and after education and $\mathrm{p}<0.05$ was considered significant in statistical analysis.

\section{Results}

Of the 297 students (before the anatomy lessons), female participants' distribution was $49.50 \%$ and the male participants' distribution was $50.50 \%$. Of the 212 students (after the anatomy lessons) it was $54.70 \%$ and $45.30 \%$, respectively (Figures 1 and 2). All students who answered the questionnaire were aged 18-24.

In response to questions about Cadaver Ethics in Section B, for the item "Have you ever lost a relative before" question, the rate of the answers as "Yes" was $69.40 \%$ in the first survey and $72.60 \%$ for the second survey. The answers as "No" responds were $30.60 \%$ and $27.40 \%$, respectively (Figures 3 and 4).

For the item "Do you know the difference between dead body and cadaver?" the rate of the answers as "Yes" was $66.30 \%$ and "No" was $33.70 \%$ in the first survey. In

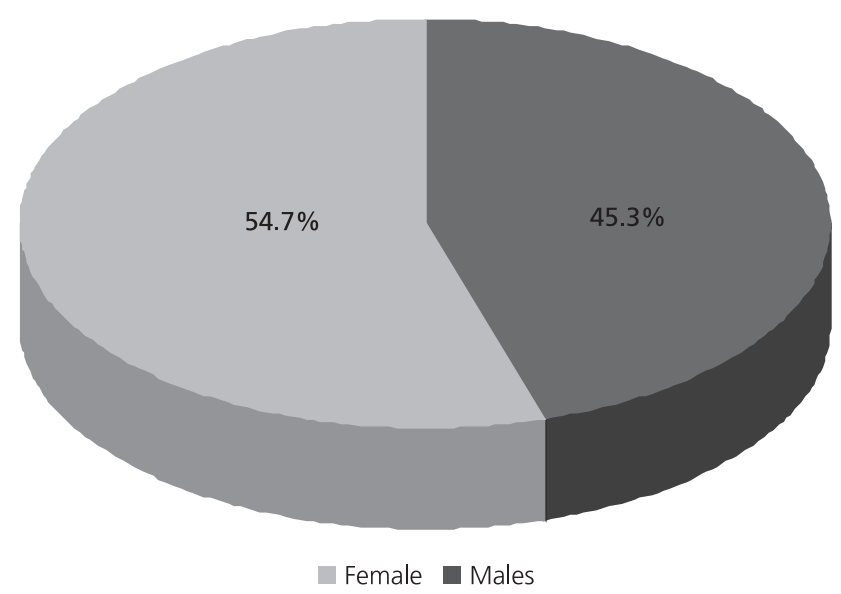

Figure 2. Age distribution of the participants of after the anatomy lessons. 


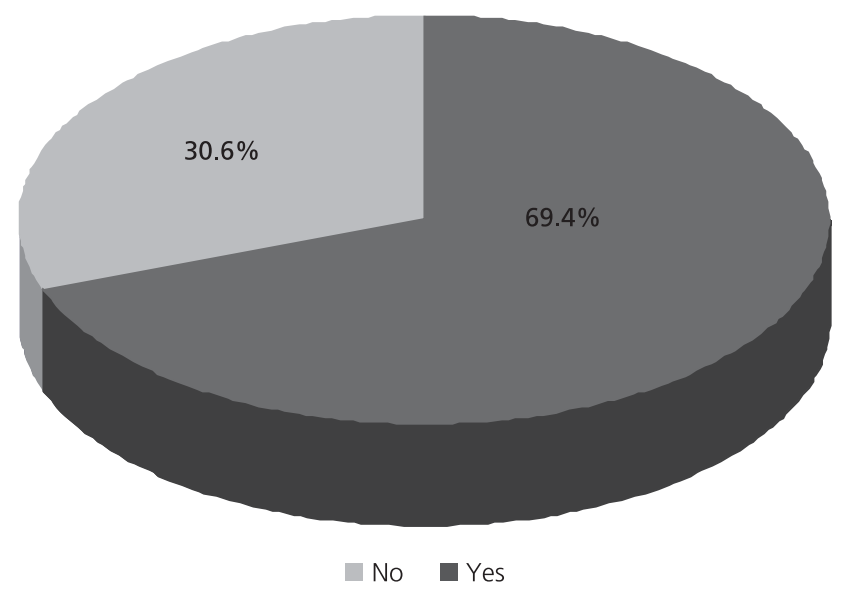

Figure 3. "Have you lost a close relative before?" answers for the first survey.

the second one, the frequency of the answers as "Yes" was 98.10\%, "No" answers were $1.90 \%$. (Figures $\mathbf{5}$ and $\mathbf{6}$ ).

Of respondents $82.50 \%$ answered as "Yes" and $17.50 \%$ answered as "No" to the item "Have you seen the cadaver before?" in the first survey. In the second survey, answers as "Yes" were $41 \%$ and "No" were $59 \%$ (Figures 7 and 8).

In response to the item "Is there any effect of having cadaver and cadaver training in Uludağ University School of Medicine in your choice of university?", the rate of the answer of "Yes" was $32.30 \%$ and "No" was $67.70 \%$ in the first, In the second survey, the rate of the "Yes" answers were $39.60 \%$ and the "No" answers were $60.40 \%$ (Figures 9 and 10).

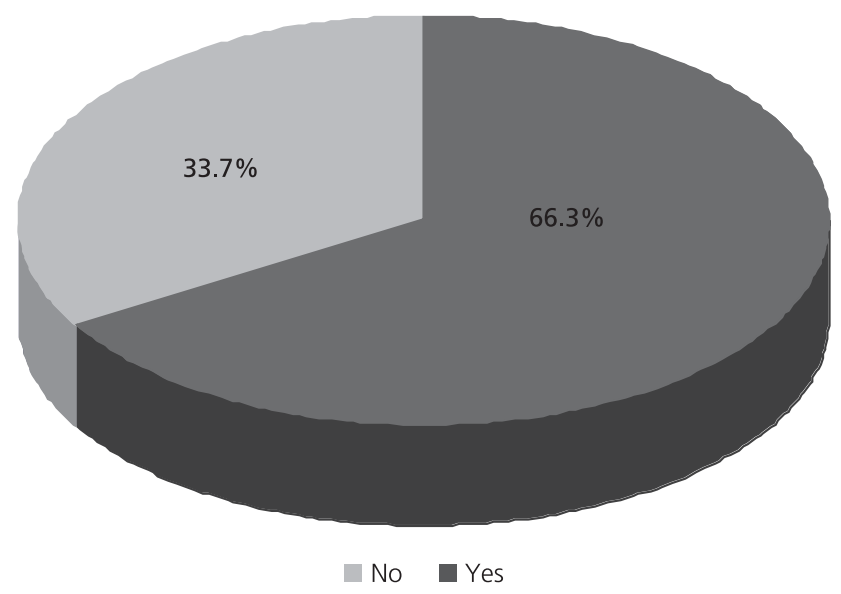

Figure 5. . "Do you know the difference between dead body and cadaver?" answers for the first survey.

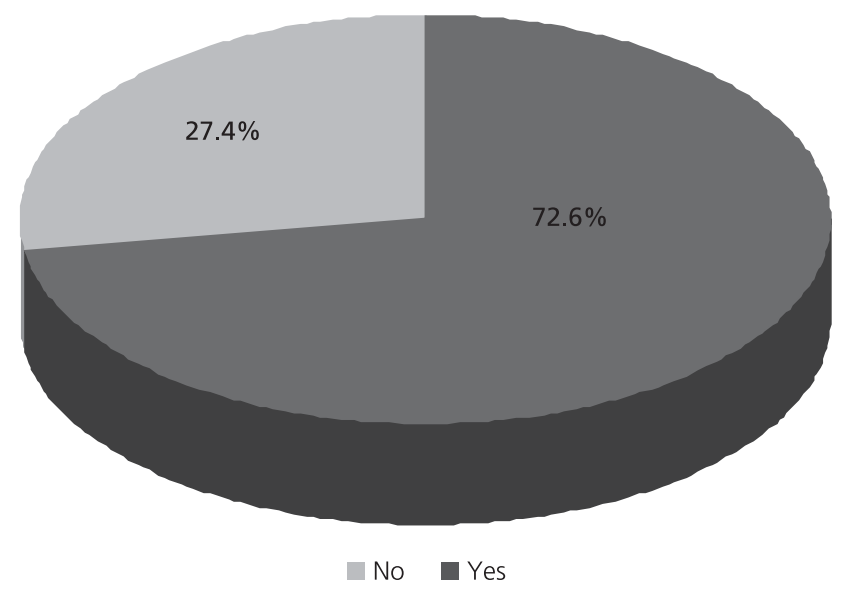

Figure 4. "Have you lost a close relative before?" answers for the second survey.

The mean and standard deviation values, before and after the Committee of the responses obtained using the Likert type scale regarding the opinions about the cadaver in the $\mathrm{C}$ section were given in Table $\mathbf{1}$ and the frequency distribution percentage values are given in Table 2 .

\section{Discussion}

Despite the developing technology, cadaver has an importance as an indispensable material for anatomy classes for medical students and educators. ${ }^{[1]}$ Particularly, the attitude of the students towards the concept of death and the moment of meeting a dead body are of the factors that can influence their education period. ${ }^{[10,12]}$ It has been a necessity to inform the students about humanity and medical

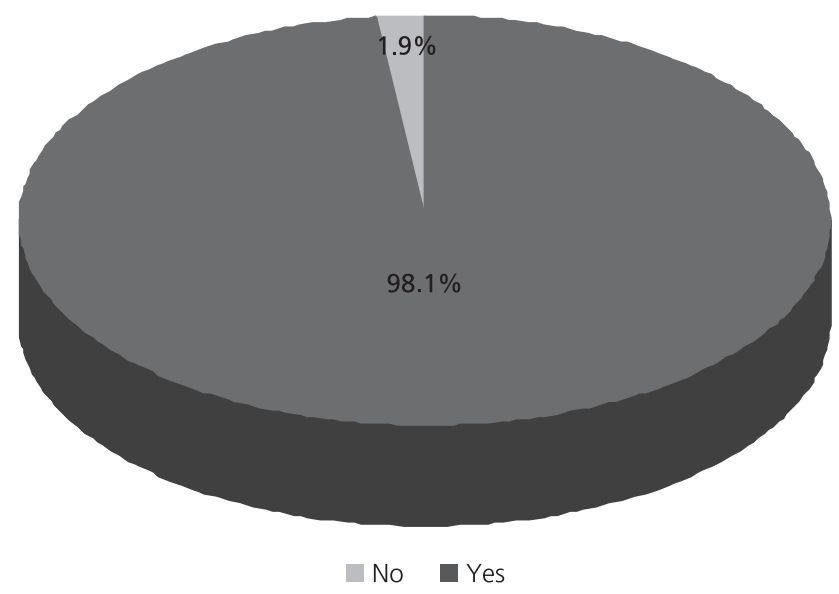

Figure 6. "Do you know the difference between dead body and cadaver?" answers for the second survey. 


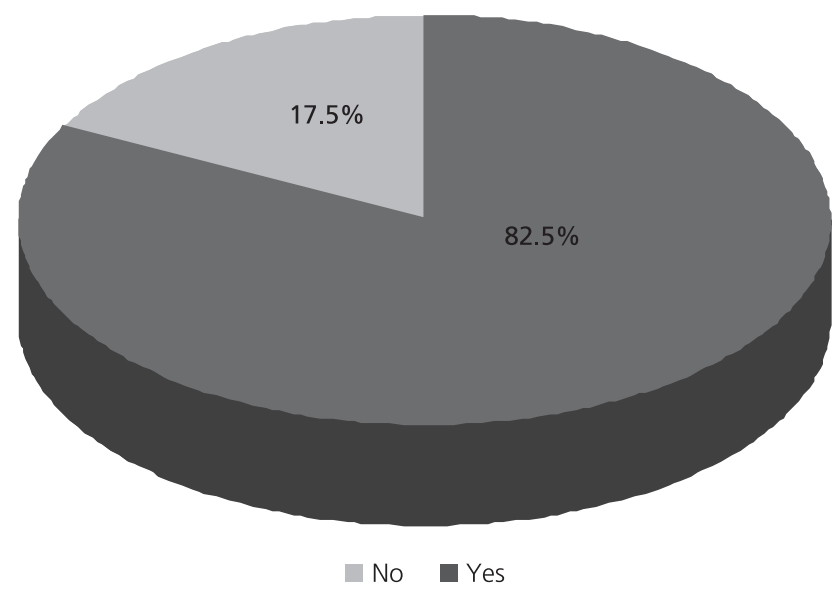

Figure 7. "Have you ever seen a cadaver before ?" answers for the first survey.

ethics and to make them feel that they should show ethical behavior in accordance with their awareness during the medical education. ${ }^{[13]}$ With this survey, we have tried to determine the attitudes of the students towards human cadavers and ethical awareness and to examine whether the pre-judgments have changed throughout their education.

For the item that "Human is a valuable asset. For this reason, the human body must be valued and respected during life and after death" while the number of students who answered "Strongly I agree" is $52.2 \%$ in the first survey, this percentage reached to $76.6 \%$ after the Committee. In the study conducted by Babacan et al. with the students of Uludağ University, the number of

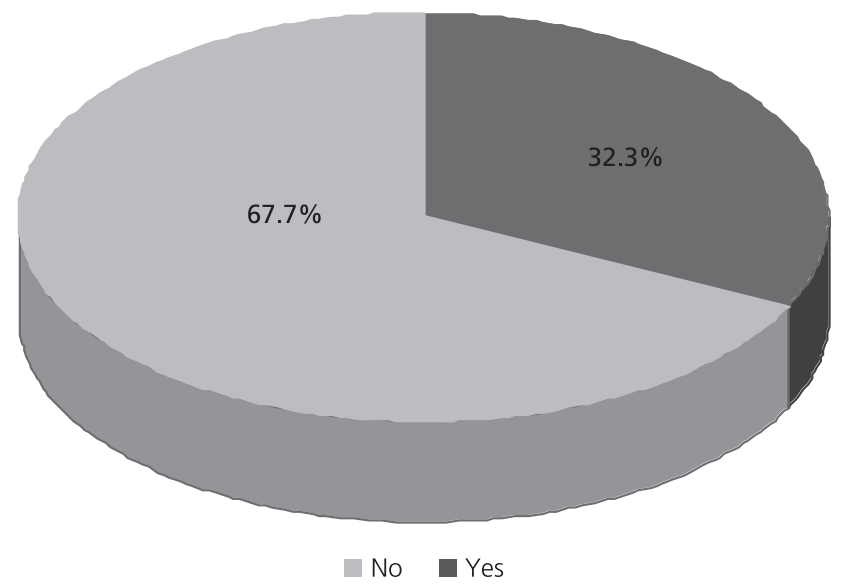

Figure 9. "Is there any effect of having cadaver and cadaver training in Uludağ University School of Medicine in your choice of university?" answers for the first survey.

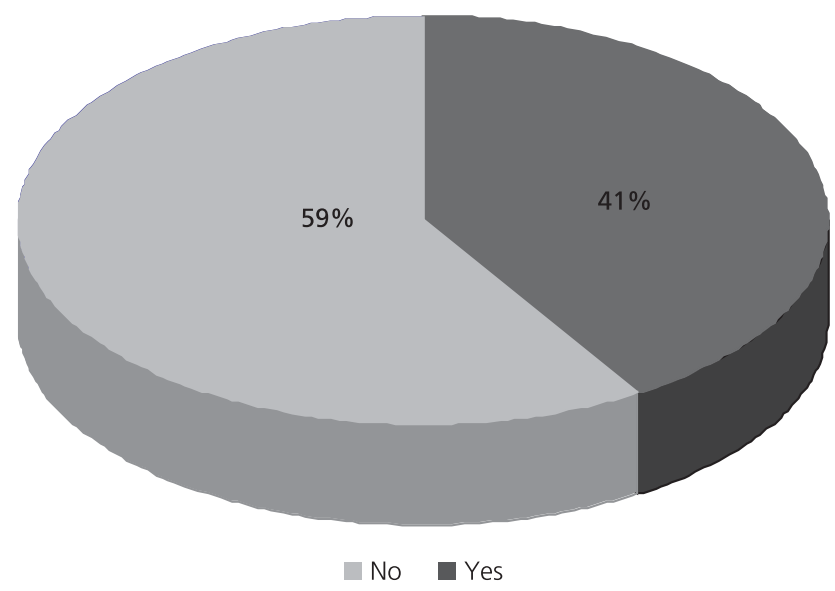

Figure 8. "Have you ever seen a cadaver before?" answers for the second survey.

respondents who answered positively to the similar question is $88.4 \%{ }^{[14]}$ The rate of positive response is $83.8 \%$ in the first survey and $95.2 \%$ in the second survey which we have done only with term I students. In another study by Babacan et al. they directed the same question to academicians who are working in different universities in Turkey, they have reported that they received 97.6\% positive responses. ${ }^{[15]} \mathrm{We}$ believe that ethical education would be more effective in increasing the value of cadavers accompanied by anatomists who accept human dignity in a positive way. It is interesting that the students who attend the classes regularly answered the same question, mean value is $3.85 \pm 0.91$ and the students who do not attend regularly at the average values is $4.22 \pm 0.78$

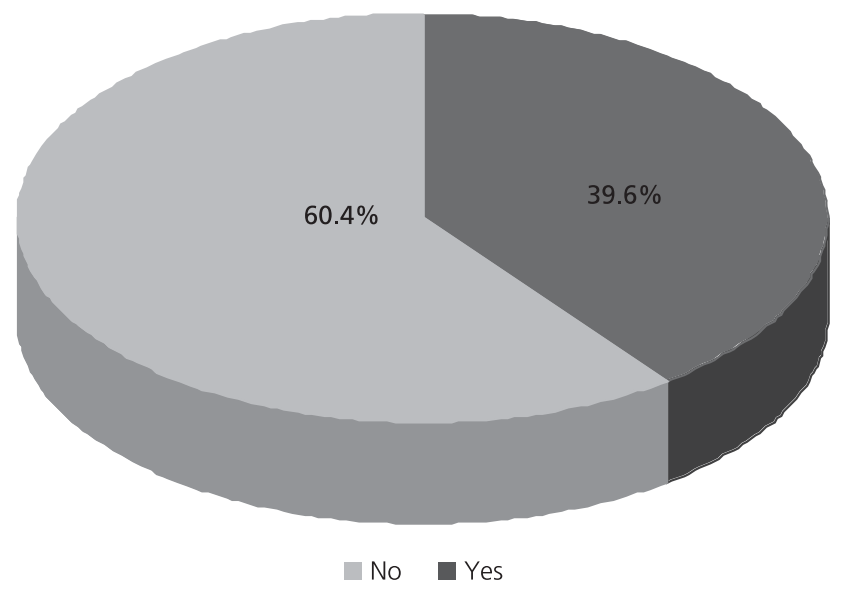

Figure 10. "Is there any effect of having cadaver and cadaver training in Uludağ University School of Medicine in your choice of university?" answers for the second survey. 
Table 1

Mean and standard deviation values before and after Committee.

\begin{tabular}{|c|c|c|c|}
\hline Questions & Before & After & p-value \\
\hline 1. Human is a valuable asset. For this reason, the human body must be valued and respected during life and after death. & $4.27 \pm 0.95$ & $4.66 \pm 0.62$ & 0.001 \\
\hline 2. The cadaver should be in a more respected position because it contributes to anatomy education. & $4.44 \pm 0.71$ & $4.63 \pm 0.55$ & 0.001 \\
\hline 3. The point of view towards the cadaver is as sensitive and important as approaching the patient. & $4.01 \pm 0.95$ & $4.05 \pm 0.92$ & 0.650 \\
\hline 4. On the right of privacy, covering the face of the cadaver during the dissection is a human delicacy that should not be neglected. & $3.84 \pm 1.03$ & $4.15 \pm 0.88$ & 0.001 \\
\hline 5. Memories taken from cadavers can be shared in social media & $1.68 \pm 0.95$ & $1.42 \pm 0.77$ & 0.001 \\
\hline 6. Cadaver dissections can be performed outside of anatomy rooms or surgical units in hospitals (congress center, hotel, etc.). & $2.02 \pm 0.99$ & $1.89 \pm 0.87$ & 0.120 \\
\hline 7. It makes me uncomfortable to see the photo or video of my acquaintance, who has donated his body, in social media. & $4.35 \pm 0.89$ & $4.58 \pm 0.73$ & 0.002 \\
\hline 8. I warn the people who share cadaver images in social media. & $3.87 \pm 0.93$ & $3.91 \pm 0.87$ & 0.595 \\
\hline 9. Cadaver dissections should not be performed except in the anatomy laboratories or surgical sciences in hospitals. & $3.96 \pm 0.98$ & $4.06 \pm 0.92$ & 0.266 \\
\hline 10. I would prefer to dissect the donated body & $3.95 \pm 0.85$ & $3.90 \pm 0.87$ & 0.515 \\
\hline 11. I would prefer to dissect the body belonging unclaimed & $2.69 \pm 0.90$ & $2.42 \pm 0.85$ & 0.001 \\
\hline 12. Education, studies and researches related to cadaver should be done only in anatomy laboratories. & $3.73 \pm 0.88$ & $3.62 \pm 0.98$ & 0.187 \\
\hline $\begin{array}{l}\text { 13. The acquisition of the sense of ethics and privacy related to the cadaver is important in terms of medical ethics and } \\
\text { patient privacy. }\end{array}$ & $4.37 \pm 0.69$ & $4.44 \pm 0.65$ & 0.241 \\
\hline 14. Lessons made with a cadaver whose integrity is impaired are affecting my education negatively. & $3.43 \pm 1.06$ & $3.81 \pm 1.11$ & 0.001 \\
\hline
\end{tabular}

after the anatomy lesson in a different study. ${ }^{[5]}$ Erbay et al. also asked the same question and they reported the average value of the students who responded to the same item is $4.27 \pm 1.04 .{ }^{[10]}$ In our study we found the same values but after education this value has increased to $4.66 \pm$ 0.62 and this result shows us the importance of Committee.

Parallel to the first item; it was anticipated that an increase in the number of positive respondents to "The cadaver should be in a more respected position because it contributes to anatomy education." is an expected result. "The point of view toward the cadaver is as sensitive and attractive as approaching the patient" item's results show that there is no statistically significant difference between before and after Committee. This results bring up to mind that students still do not have a patient's sensitivity to cadaver even they have respect.

"On the right of privacy, covering the face of the cadaver during the dissection is a human delicacy that should not be neglected" it is still a controversial subject and is sometimes criticized by students during the courses. For this item, Erbay et al. 2015 reported that mean value is $3.27 \pm 1.19$ over 5 , Ogenler et al. 2014 reported data as $6.01 \pm 3.30$ over $10 .^{[9,10]}$ In our study, the values we have determined were $3.84 \pm 1.03$ before Committee and $4.15 \pm 0.88$ after education. This results have showed us the importance of the Committee once again.

The sharing of photographs taken with cadaver in social media has been one of the issues that has been still being discussed ethically however seen that such violations continue. The rate of the answers given negatively to the item "Memories taken from cadavers can be shared in social media" before education was $7.1 \%$ and after course this value decreased to $4.8 \%$. This results showed that some of the students' ideas have changed about cadaver. It was seen that this value was $1.2 \%$ in the study conducted with the academicians. ${ }^{[15]}$ In parallel with this item, it was expected to see the same result as "It makes me uncomfortable to see the photo or video of my acquaintance, who has donated his body, in social media". It was encouraging that the attitudes of the students in warning the photographers are also positive in the pre-training period.

When the answers to the question asked about "Where the cadaveric dissections should be done" were examined, it was seen that the idea of "Dissections could be done not only in the anatomy rooms but also in the surgical units, but that no dissection should be done except these units" were positively at two surveys (77.1\% and $79.2 \%$, respectively). Regarding the situation on the cadavers they work on; it was seen that working with orphaned cadavers disturbed the students after committee while cadaver donation did not affect the students in the before Committee surveys. But the number of students who were undecided about this issue was not negligible. The rate of students who thought about the orphaned cadaver was negatively $47.7 \%$ and the number of undecided students was $45.7 \%$. 
Table 2

Frequency distribution before and after Committee percentage values.

\begin{tabular}{|c|c|c|c|c|c|c|}
\hline Questions & & $\begin{array}{l}\text { Strongly } \\
\text { Disagree }\end{array}$ & Disagree & Undecided & Agree & $\begin{array}{l}\text { Strongly } \\
\text { Agree }\end{array}$ \\
\hline \multirow{2}{*}{$\begin{array}{l}\text { 1. Human is a valuable asset. For this reason, the human body must be valued and } \\
\text { respected during life and after death. }\end{array}$} & Before & $2.1 \%$ & $4.7 \%$ & $9.4 \%$ & $31.6 \%$ & $52.2 \%$ \\
\hline & After & $0.5 \%$ & $0.5 \%$ & $3.8 \%$ & $22.6 \%$ & $72.6 \%$ \\
\hline \multirow{2}{*}{$\begin{array}{l}\text { 2. The cadaver should be in a more respected position because it contributes to } \\
\text { anatomy education. }\end{array}$} & Before & $1.2 \%$ & $1.2 \%$ & $3.2 \%$ & $41.2 \%$ & $53.2 \%$ \\
\hline & After & $0.1 \%$ & $0.9 \%$ & $0.9 \%$ & $31.6 \%$ & $66.5 \%$ \\
\hline \multirow{2}{*}{$\begin{array}{l}\text { 3. The point of view towards the cadaver is as sensitive and important as } \\
\text { approaching the patient. }\end{array}$} & Before & $1.4 \%$ & $6.7 \%$ & $16.2 \%$ & $40.7 \%$ & $35.0 \%$ \\
\hline & After & $0.5 \%$ & $7.1 \%$ & $16.0 \%$ & $39.6 \%$ & $36.8 \%$ \\
\hline \multirow{2}{*}{$\begin{array}{l}\text { 4. On the right of privacy, covering the face of thecadaver during the dissection is } \\
\text { a human delicacy that should not be neglected. }\end{array}$} & Before & $2.7 \%$ & $8.1 \%$ & $22.2 \%$ & $36.0 \%$ & $31.0 \%$ \\
\hline & After & $1.5 \%$ & $4.2 \%$ & $11.3 \%$ & $43.4 \%$ & $39.6 \%$ \\
\hline \multirow[t]{2}{*}{ 5. Memories taken from cadavers can be shared in social media. } & Before & $55.2 \%$ & $30.0 \%$ & $7.7 \%$ & $5.1 \%$ & $2.0 \%$ \\
\hline & After & $68.4 \%$ & $25.9 \%$ & $1.9 \%$ & $2.4 \%$ & $1.4 \%$ \\
\hline \multirow{2}{*}{$\begin{array}{l}\text { 6. Cadaver dissections can be performed outside of anatomy rooms or surgical } \\
\text { units in hospitals (congress center, hotel, etc.). }\end{array}$} & Before & $34.3 \%$ & $39.4 \%$ & $18.9 \%$ & $4.4 \%$ & $3.0 \%$ \\
\hline & After & $37.3 \%$ & $41.5 \%$ & $17.4 \%$ & $2.4 \%$ & $1.4 \%$ \\
\hline \multirow{2}{*}{$\begin{array}{l}\text { 7. It makes me uncomfortable to see the photo or video of my acquaintance, who } \\
\text { has donated his body, in social media. }\end{array}$} & Before & $1.7 \%$ & $4.0 \%$ & $6.1 \%$ & $33.3 \%$ & $54.9 \%$ \\
\hline & After & $0.9 \%$ & $1.9 \%$ & $3.4 \%$ & $25.9 \%$ & $67.9 \%$ \\
\hline \multirow[t]{2}{*}{ 8. I warn the people who share cadaver images in social media. } & Before & $1.7 \%$ & $6.4 \%$ & $21.9 \%$ & $43.1 \%$ & $26.9 \%$ \\
\hline & After & $0.9 \%$ & $5.3 \%$ & $21.2 \%$ & $46.7 \%$ & $25.9 \%$ \\
\hline \multirow{2}{*}{$\begin{array}{l}\text { 9. Cadaver dissections should not be performed except in the anatomy laboratories } \\
\text { or surgical sciences in hospitals. }\end{array}$} & Before & $3.7 \%$ & $4.4 \%$ & $14.8 \%$ & $45.5 \%$ & $31.6 \%$ \\
\hline & After & $1.9 \%$ & $4.7 \%$ & $14.2 \%$ & $43.4 \%$ & $35.8 \%$ \\
\hline \multirow[t]{2}{*}{ 10. I would prefer to dissect the donated body } & Before & $0.0 \%$ & $5.1 \%$ & $23.6 \%$ & $42.1 \%$ & $29.2 \%$ \\
\hline & After & $0.5 \%$ & $5.2 \%$ & $25.0 \%$ & $42.0 \%$ & $27.3 \%$ \\
\hline \multirow[t]{2}{*}{ 11. I would prefer to dissect the body belonging unclaimed } & Before & $11.8 \%$ & $23.2 \%$ & $50.8 \%$ & $11.8 \%$ & $2.4 \%$ \\
\hline & After & $17.0 \%$ & $30.7 \%$ & $45.7 \%$ & $6.1 \%$ & $0.5 \%$ \\
\hline \multirow{2}{*}{$\begin{array}{l}\text { 12. Education, studies and researches related to cadaver should be done only in } \\
\text { anatomy laboratories. }\end{array}$} & Before & $1.0 \%$ & $8.8 \%$ & $23.2 \%$ & $49.5 \%$ & $17.5 \%$ \\
\hline & After & $1.9 \%$ & $12.3 \%$ & $25.4 \%$ & $42.0 \%$ & $18.4 \%$ \\
\hline \multirow{2}{*}{$\begin{array}{l}\text { 13. The acquisition of the sense of ethics and privacy related to the cadaver } \\
\text { is important in terms of medical ethics and patient privacy. }\end{array}$} & Before & $0.7 \%$ & $1.7 \%$ & $3.4 \%$ & $47.7 \%$ & $46.5 \%$ \\
\hline & After & $0.9 \%$ & $0.5 \%$ & $1.9 \%$ & $46.2 \%$ & $50.5 \%$ \\
\hline \multirow{2}{*}{$\begin{array}{l}\text { 14. Lessons made with a cadaver whose integrity is impaired are affecting my } \\
\text { education negatively. }\end{array}$} & Before & $5.4 \%$ & $11.8 \%$ & $32.7 \%$ & $34.3 \%$ & $15.8 \%$ \\
\hline & After & $4.2 \%$ & $9.0 \%$ & $20.7 \%$ & $34.0 \%$ & $32.1 \%$ \\
\hline
\end{tabular}

In a study conducted with two groups of the second term students of the School of medicine of Ege University. One group was given an education on cadaver, donation, life and death prior to the Anatomy class and another group wasn't given that education. When the situation students were examined at the end of the year, it was seen that the students who took the course were more successful. ${ }^{[16]}$

In the study based on the opinions of School of Medicine of Bursa Uludağ University students' on cadaver in $2003,92.2 \%$ of the students reported that they could not be educated well on anatomy without cadaver. ${ }^{[17]}$ In the study conducted with the students of the School of Medicine, Akdeniz University, $84.3 \%$ of the first term students indicated that cadaver had an important place in anatomy education, also $96.8 \%$ of the students of the second term responded positively on the same idea. ${ }^{[18]}$ These results show that the awareness of the students has been increasing in the education process.

\section{Conclusion}

Anatomy education not only teaches the morphological aspect of the human body but also contributes to the conception of patient confidentiality and medical ethics through attitude towards cadavers. Ethical education courses can be given to the students to ensure a respectable attitude against the cadaver. Remembering that every person is a respectable being is a rule that should not be forgotten for all of us. With this survey study, we intended to reveal the effects of the concept of ethics on medical students. Furthermore, this study also investigates the demographic information, especially the gender factor, which has an effect on attitudes and behaviors using the statistical analyzes. 


\section{References}

1. Yilmaz ST, Yilmaz C. Body: from anatomical theatres to galleries. [Article in Turkish] Lokman Hekim Tip Dergisi 2016;6:46-52.

2. Ghosh SK. Human cadaveric dissection: a historical account from ancient Greece to the modern era. Anat Cell Biol 2015;48:153-69.

3. Gürbüz H, Karlıkaya E, Mesut R. Opinions about bequeathed cadavers. [Article in Turkish] Türkiye Klinikleri Journal of Medical Ethics 2004;12:234-41.

4. Nurunnabi ASM, Ara S, Khalil M, Khalil M. Ethics in dissection of cadaver in teaching and learning of anatomy. Bangladesh Journal of Bioethics 2011;2:10-5.

5. Dissabandra LO, Nirthanan SN, Khoo TK, Tedman R. Role of cadaveric dissections in modern medical curricula: a study on student perceptions. Anat Cell Biol 2015;48:205-12.

6. Chen S, Pan Z, Wu Y, Gu Z, Li M, Zhu H, Yao Y, Shui W, Shen Z, Zhao J, Pan H. The role of three-dimensional printed models of skull in anatomy education: a randomized controlled trail. Nature Scientific Reports, 2017. doi:10.1038/s41598-017-00647-1

7. Sayek İ, Odabaşı O, Kiper N. Türk Tabipleri Birliği Mezuniyet Öncesi Tıp Eğitimi Raporu-2010. Ankara: Türk Tabipleri Birliği Yayınları.

8. Tulgar ŞF. Tip fakültelerinde mezuniyet öncesi anatomi eğitiminin ögrenci geribildirimleri ile değerlendirilmesi. Balıkesir Üniversitesi Sağlık Bilimleri Enstitüsü, Yüksek Lisans Bitirme Tezi 2014.

9. Ögenler O, Kara A, Kadıŏlu S, Öztürk H, Sungur MA. Opinions of a group of anatomy instructors on cadaver and utilization of cadaver

ORCID ID:

N. Tuncel Çini 0000-0003-1412-2634; S. Babacan 0000-0002-7410-7738; I. M. Kafa 0000-0001-8309-0934; S. Erer Kafa 0000-0001-8926-996X in anatomy teaching. [Article in Turkish] Türkiye Biyoetik Dergisi 2014;1:57-68.

10. Erbay H, Bilir A, Gönül Y, Turamanlar O, Songur A. Medical students' perception of cadaver and, their attitudes towards using the cadaver in education. [Article in Turkish] Türkiye Biyoetik Dergisi 2015;2:63-72.

11. Chapman SJ, Hakeem AR, Marangoni G, Prasad GR. Anatomy in medical education: perceptions of undergraduate medical students. Ann Anat 2013;195:409-14.

12. Winkelmann A, Guldner FH. Cadavers as teachers: the dissecting room experience in Thailand. BMJ 2004;329(7480):1455-7.

13. Altan S, Rahman S, A, Çam S. The knowledge levels of the students taking pre-clinical medical school education, about medical ethics. [Article in Turkish] Firat Tip Dergisi 2013;18:109-16.

14. Babacan S, Erer Kafa S, Kafa İM. Approach to cadaver used in anatomy education, dead body confidentiality and ethics II: Uludağ University Faculty of Medicine students' opinions. [Abstract] Anatomy 2017;11:S97-8.

15. Babacan S, Kafa İM, Erer Kafa S. Approach to cadaver used in anatomy education, dead body confidentiality and ethics I: opinions of anatomy academicians. [Abstract] Anatomy 2017;11:S97.

16. Saylam C, Coskunol H. Orientation lesson in anatomy education. Surg Radiol Anat 2005;27:74-7.

17. Arı İ, Şendemir E. Students' views on anatomy education. [Article in Turkish] Uludağ Üniversitesi Tip Fakültesi Dergisi 2003;29(2):11-4.

18. Sindel M, Şenol, Y, Gürpınar E. Evaluation of anatomy education by students in Akdeniz University School of Medicine. [Article in Turkish] Tıp Eğitimi Dünyası 2008;(28):31-6.

Correspondence to: Sezer Erer Kafa, MD

Department of Medical Ethics and History of Medicine, School of Medicine, Bursa Uludağ University Bursa, Turkey

Phone: +902242953960

e-mail: sezer@uludag.edu.tr

Conflict of interest statement: No conflicts declared.

This is an open access article distributed under the terms of the Creative Commons Attribution-NonCommercial-NoDerivs 3.0 Unported (CC BY-NCND3.0) Licence (http://creativecommons.org/licenses/by-nc-nd/3.0/) which permits unrestricted noncommercial use, distribution, and reproduction in any medium, provided the original work is properly cited. Please cite this article as: Tuncel Çini N, Babacan S, Kafa IM, Erer Kafa S. Cadavers in anatomy classes: opinions of the students of Bursa Uludağ University School of Medicine. Anatomy 2019;13(1):49-55. 